Jurnal IImiah Dikdaya, 11(2), September 2021, 331-335

Publisher: Fakultas Keguruan dan IImu Pendidikan Universitas Batanghari Jambi ISSN 2088-5857(Print), ISSN 2580-7463 (Online)

DOI 10.33087/dikdaya.v11i1.1...

\title{
The Effect of Using Zoom Conference System on Students' Speaking Skills
}

\author{
${ }^{1}$ Wahyudi Daud dan ${ }^{2}$ Asri Nofa Rama \\ ${ }^{1}$ Lecturer of Lakidende University \\ ${ }^{2}$ Lecturer of Lakidende University \\ Correspondence Email: Asrirama21@gmail.com
}

\begin{abstract}
The objective of this study is to investigate the effects of using zoom conference system on students' speaking skill. This research is classified into pre-experimental research that uses one group pre-test and post-test. In the one group pre-test and post-test design, a single group is measured or observed not only after being treatment, but also before the treatment. The data of this research analyzed by using Statistical Package for the Social Science (SPSS, version 24.0) where the data of this study include quantitative data, namely students speaking skill on pre-test and post-test. Therefore, the data are analyzed by using descriptive statistic, while to test the hypothesis, the researcher used Paired Sample t-test to draw the conclusion whether or not it is accepted. The finding revealed that Zoom conferencing strategy has a noteworthy impact on students' Speaking Skill. The probability value ( $p$ value) is less than the level of significant which $p$ value is $0.000<0.05$ (alpha value). Means, there is difference mean score on pre-test and post-test in experimental class.
\end{abstract}

Keywords: Speaking Skill, Zoom Conference System

\begin{abstract}
Abstrak: Tujuan dari penelitian ini adalah untuk mengetahui pengaruh penggunaan sistem konferensi zoom terhadap keterampilan berbicara siswa. Penelitian ini tergolong penelitian pra-eksperimen yang menggunakan one group pre-test dan posttest. Dalam one group pre-test and post-test design, satu kelompok diukur atau diamati tidak hanya setelah diberi perlakuan, tetapi juga sebelum diberi perlakuan. Data penelitian ini dianalisis dengan menggunakan Statistical Package for the Social Science (SPSS, versi 24.0) dimana data penelitian ini meliputi data kuantitatif yaitu keterampilan berbicara siswa pada pre-test dan posttest. Oleh karena itu, data dianalisis dengan menggunakan statistik deskriptif, sedangkan untuk menguji hipotesis peneliti menggunakan Paired Sample t-test untuk menarik kesimpulan diterima atau tidak. Temuan ini mengungkapkan bahwa strategi konferensi Zoom memiliki dampak penting pada Keterampilan Berbicara siswa. Nilai probabilitas (p value) lebih kecil dari taraf signifikan yaitu $\mathrm{p}$ value $0,000<0,05$ (alpha value). Artinya, ada perbedaan rata-rata skor pre-test dan post-test di kelas eksperimen.
\end{abstract}

Kata kunci: Keterampilan Berbicara, Zoom Conference System

\section{INTRODUCTION}

In Indonesia, English is taught as a foreign language based on the guidance namely curriculum which is always provided with syllabus. As a compulsory subject, English language is taught from elementary school up to university level. There are four language skills to be taught to the students, they are: speaking, listening, reading, and writing. From these four language skills, speaking might be the most important one to be learned because when students learn foreign language, it is considered to be successful if they can communicate effectively in their second or foreign language.

Speaking is the way to communicate with other people, while in Indonesia English is learned only at school and people do not speak the language in the society. That is why teaching speaking must be focused at school in order to make them capable to speak English well. However, during the pandemic Covid -19 the English teachers get some problems in delivering the material, therefore to overcome this problem the educational institution must be aware of the influence and outcome of the technologies that have been used for facilitating learning pathways. It's also equally important for the teacher to selecting the appropriate media to help students develop their skills in the target language.

One of media that supported for teaching and learning process in pandemic covid-19 is by using zoom conference system. Zoom conferencing has been defined as "synchronous audio and video communication through computer and telephone networks between two or more geographically dispersed sites" (Lawson, Comber, Gage \& Cullum-Hanshaw, 2010, p. 295). Additionally, communication through Zoom conferencing includes eye contact, gestures and turn-taking, which can enhance students' positive attitudes and motivation to learn the target language (Jauregui, Graff, Bergh \& Khriz, 2012). Therefore, 
Wahyudi Daud dan Asri Nofa Rama, The Effect of Using Zoom Conference System on Students' Speaking Skills

students are provided with the opportunity to engage in authentic interactions and practice how to negotiate meaning and learn different ways of expressing their views as they change from learning a language to using it (Alshahrani, 2016).

For a decade, great deal of research examining not only in Indonesia but also in other countries. However, research that has been conducted about the effect of using zoom conference system on students' speaking skill, especially with the student populations of Indonesia is relatively little. In detail, for the University of Indonesia, namely Lakidende University based on a search of databases and local journals, no single article has been published regarding the effect of using zoom conference system on students' speaking skill, this is particularly surprising if we look at the immense growing popularity of technology in Pandemic Covid-19 right now. Obviously, examining the effect of using zoom conference system, especially for speaking skill is crucial as an informed the importance of technology particularly in language learning context.

\section{LANDASAN TEORI Speaking}

Speaking is the verbal use of language to communicate with other. In additional, Hughes explain that speaking in interactive andaccording to accomplish pragmatic goals through interactive discourse with other speaker of language.

Speaking is one of the 4 language skills available (writing, listening reading and speaking). The importance of improving one's ability to speak so that what is conveyed to structure and has more value to what is conveyed. Someone who has good speaking skills can be said that the other three language skills are also quite good, because someone who is able to speak well is certainly more read, write and hear. According to Byrne (1986), speaking is 'oralcommunication' in a two way process between the speaker and listener(s) involving both productive (i.e. speaking) and receptive skills (i.e. listening with understanding).

\section{Zoom Application}

Media is everything that can channel information from source of information to the recipient of the information. The role of media in the learning process can be defined as the technology of messenger (information) that can be utilized for teaching purposes or physical means to deliver content / subject matter.

Generation $\mathrm{Z}$ children of this era are the generation born in increasingly sophisticated times so that the learning styles andmedia used are very global and visual. From the results of his research that learning media using video is very helpful in the learning process both formal and informal (Denissa, 2016: 85). Learning media is very influential on the success of a teacher in conducting the learning process. Choosing the right learning media will have an impact on learning outcomes that will be received by students, if the learning media used by the teacher can facilitate students in the learning process then students will be interested in continuing to learn and will easily understand the learning delivered.

Educational media classification according to Sulaiman(1985: 27) is as follows, (1) audio media, namely media that can produce sounds such as cassettes, tape recorders, and radios; (2) visual media that is media that can show form or form. Currently in the world of education use more visual media to do the learning process, in addition to listening to sound, can also see pictures so that teachers and students can interact more easily, for example, the use of the zoom application as a learning medium especially in learning English.

Zoom is an application made by billionaire Eric Yuan, which was established in April 2011. Besides the application, Zoom can also be accessed via the website, both for Mac OS, Windows, Linux, iOS, and Android. According to Dinda Silviana Dewi Zoom is a communication application using video. The application can beused on a variety of mobile devices, desktops, to telephones and space systems.

According to Kevin in Kompas.com stated that zoom as video conferencing is widely used by various groups such as distance learning by lecturers and students because the quality of video and audio can be maintained even though the internet connection is unstable. 
Wahyudi Daud dan Asri Nofa Rama, The Effect of Using Zoom Conference System on Students' Speaking Skills

Zoom Cloud Meeting is an application that can support communication needs wherever and whenever with many people without having to meet physically in person. This application is for video conferencing, it can easily be installed on several devices like; PC (Personal Computer) with webcame, Laptop with webcame, Android / iOS Smartphone.

\section{METHODS}

This research is classified into pre-experimental research that uses one group pre-test and post-test. In the one group pre-test and post-test design, a single group is measured or observed not only after being treatment, but also before the treatment. Pre-test provides a measure on some attribute or characteristic that is assessed in an experiment before the group gets a treatment, while in the post-test measure on some attribute or characteristic that assessed for participants in an experiment after the treatment. The reason why the researcher uses pre experimental design is because the limited of time and the pandemic covid- 19 . It can be seen clearly in the following scheme:

Pre- Test

$\mathbf{O}_{1}$

$\mathrm{O}_{1}$

$\mathrm{X}$

$\mathrm{O}_{2}$ Treatment

$\mathbf{X}$
Post-Test

$\mathbf{O}_{2}$

: students' achievement on speaking skill before treatment.

: Speaking Skill through Zoom Conference treatment

: students' achievement on speaking skill after treatment.

\section{FINDINGS}

Table 1.

Descriptive analysis of Pre Test and Post Test Descriptive Statistics

\begin{tabular}{|l|r|r|r|r|r|}
\hline & N & Minimum & Maximum & Mean & Std. Deviation \\
\hline PreTest & 30 & 76 & 85 & 78.43 & 2.344 \\
PostTest & 30 & 77 & 88 & 83.00 & 2.948 \\
Ngain & 30 & 2 & 72 & 37.67 & 21.284 \\
Valid N (listwise) & 30 & & & \\
\hline
\end{tabular}

Based on the description of students' score above, it can be concluded that the students' score on post test is higher or better than the students' score on pre test, in which the mean score on pre test is 78.43 while the mean score on post test is 83.00. It means that the increasing of students' average score from pre test to post test is 4.57 Hence, the students' speaking skill that is taught by zoom conferencing system has more significant effect.

Table 2.

\section{Frequencies of Scale Criteria of Speaking}

\begin{tabular}{|l|c|c|c|c|c|c|c|c|c|c|}
\hline \multirow{3}{*}{ Criteria } & \multicolumn{9}{|c|}{ Numbers of Students } \\
\cline { 2 - 13 } & \multicolumn{2}{|c|}{ Pron } & \multicolumn{2}{c|}{ GA } & \multicolumn{2}{c|}{ Voc } & \multicolumn{2}{c|}{ Flue } & \multicolumn{2}{c|}{ IC } \\
\cline { 2 - 12 } & Pre & Post & Pre & Post & pre & Post & Pre & Post & \multirow{2}{*}{ Pre } & Post \\
\hline Very Poor & 0 & 0 & 2 & 0 & 3 & 0 & 1 & 0 & 0 & 0 \\
\hline Poor & 15 & 8 & 18 & 6 & 9 & 5 & 6 & 0 & 13 & 1 \\
\hline Average & 10 & 9 & 5 & 18 & 15 & 16 & 16 & 11 & 14 & 10 \\
\hline Good & 5 & 8 & 5 & 2 & 2 & 3 & 5 & 16 & 2 & 10 \\
\hline Very Good & 0 & 5 & 0 & 4 & 1 & 6 & 2 & 3 & 1 & 9 \\
\hline
\end{tabular}


Wahyudi Daud dan Asri Nofa Rama, The Effect of Using Zoom Conference System on Students' Speaking Skills

Total Numbers

Of

Students
$30 \quad 30$
30
30
30
30
30
30

The total numbers of students of experiment Class are 30 students. Number 0 shows that there is no student getting those categories. From the table above, it can be seen that there was improvement in experiment in the criteria of "very poor". There was no student who got this kind of criteria in posttest. Except pronunciation, EG had increased the numbers of students in the criteria of "very good" from 0 students to 5 students in Pronunciation Categori (Pron), from 0 student to 4 students in Grammatical Accuracy (GA), from 1 students to 6 students in Vocabulary (Voc), from 2 student to 3 students in Fluency (Flue), and from 1 student to 9 students in Interactive Communication (IC).

\section{Normality Test}

Before analyzing the statistical result, the researcher conducted normality test to know whether the data were normal or not to be tested. Shapiro Wilk test was used to show that the sample comes from particular distribution. If the result is not significant $(\mathrm{P}>0.05)$, the data have normal distribution. The result of the normality test is presented briefly in the following table:

Table 3.

Tests of Normality

\begin{tabular}{|r|r|r|r|r|r|r|r|}
\hline & \multirow{3}{*}{} & \multicolumn{3}{|c|}{ Kolmogorov-Smirnov $^{\mathrm{a}}$} & \multicolumn{3}{|c|}{ Shapiro-Wilk } \\
\cline { 3 - 8 } & Kelompok & Statistic & \multicolumn{1}{c|}{$\mathrm{df}$} & \multicolumn{1}{c|}{ Sig. } & Statistic & \multicolumn{1}{c|}{ df } & \multicolumn{1}{c|}{ Sig. } \\
\hline Hasil & PreTest & .200 & 30 & .044 & .845 & 19 & .550 \\
& PostTest & .251 & 30 & .000 & .876 & 30 & .232 \\
\hline
\end{tabular}

a. Lilliefors Significance Correction

The result shows that the Shapiro-Wilk score in Pre test is $0.550\left(\mathrm{P}_{\text {value }}>0.05\right)$, while the result of normality Pretest is $0.232\left(\mathrm{P}_{\text {value }}>0.05\right)$ which is higher than 0.05 . it can be inferred that all the data both pre test and post test are normally distribute. It meant that it was acceptable to be analyzed through parametric statistic test in form of Paired Sampel Test analysis in SPSS 24 for windows.

Table 4.

Paired Sample t-test (t test Statistics of Experimental Group Pretest and Posttest)

Paired Samples Test

\begin{tabular}{|c|c|c|c|c|c|c|c|c|}
\hline & \multicolumn{5}{|c|}{ Paired Differences } & \multirow[b]{3}{*}{$\mathrm{t}$} & \multirow[b]{3}{*}{ df } & \multirow{3}{*}{$\begin{array}{l}\text { Sig. }(2- \\
\text { tailed) }\end{array}$} \\
\hline & \multirow[b]{2}{*}{ Mean } & \multirow{2}{*}{$\begin{array}{c}\text { Std. } \\
\text { Deviation } \\
\end{array}$} & \multirow{2}{*}{$\begin{array}{l}\text { Std. Error } \\
\text { Mean }\end{array}$} & \multicolumn{2}{|c|}{$\begin{array}{l}95 \% \text { Confidence Interval of } \\
\text { the Difference }\end{array}$} & & & \\
\hline & & & & Lower & Upper & & & \\
\hline $\begin{array}{ll}\text { Pair 1 } & \text { PreTest - } \\
& \text { PostTest }\end{array}$ & 4.567 & 2.128 & .389 & 5.361 & 3.772 & 11.752 & 29 & .000 \\
\hline
\end{tabular}

Table above shows that statistical analysis of Paired Sample t-test has been conducted to compare result for pre and post test students' Speaking Skill. Theoretically, if $\mathrm{t}_{\text {count }}>\mathrm{t}$ table $(\alpha=0.05), \mathrm{H}_{0}$ is rejected, while if $\mathrm{t}$ count $\leq \mathrm{t}_{\text {table }}\left(\alpha=0.05, \mathrm{H}_{0}\right.$ is accepted (Ronald A. Fisher, 1990). The result shows that Zoom conferencing strategy has a noteworthy impact on students' Speaking Skill. The probability value $\left(p_{\text {value }}\right)$ is less than the level of significant which $p$ value is $0.000<0.05$ (alpha value). Means, there is difference mean score on pre test and posttest in experimental class. 


\section{DISCUSSION}

First and foremost, this research examined whether or not significant effect exist in students' pretest and posttest speaking skills as a result of experiencing students' zoom conference system as media at Lakidende University. The findings revealed that there is significant effect exist in students' pre-test and posttest writing ability as a result of experiencing instruction using zoom conference system. On other words, there is a significant score difference on students' speaking skill before and after they are taught by using the zoom conference system as teaching media. These findings suggested that zoom conference system affect students' speaking skill due to it engage student who did not always follow the speaking subject during pandemic covid 19. It reinforce the material, and can stimulate them to adopt a self-learning approach and collaborate with each other so as to develop their communicative competence. This finding is consistent with the result of a research by Vurdien (2019), that the use of videoconferencing was significantly effective in students' communicative competence. Furthermore, Arroyani (2018) mentions the results indicated that the achievement in the students' speaking skill through You Tube video project was improved. The advantages of You Tube video project is provides the students with opportunity to practice their speaking performance in the form of role play, drama, presentation, and simulation which are recorded in the video.

\section{COCLUSSION}

To improve language skill mastery, the students are demanded to have more practice not only in the classroom but also outside of the class. According to the findings and discussion, it is concluded that Zoom Conferencing System is an alternative way to facilitate the students to be more independent to learn language outside the class in pandemic covid-19 because the students are provided an opportunity to have more practice in speaking, and to have more experience in using supporting technology. Thus, they have more chance to improve their language skill, especially speaking skill, independently.

Based on the statistical result of pretest and posttest it shows that Zoom conferencing strategy has a noteworthy impact on students' Speaking Skill. The probability value ( $p$ value $)$ is less than the level of significant which $p$ value is $0.000<0.05$ (alpha value). Means, there is difference mean score on pre test and post test in experimental class.

\section{REFERENCES}

Hampel, R., \& Stickler, U. (2012). The use of video conferencing to support multimodal interaction in an online language classroom. ReCALL, 24(2), 116-137. doi:10.1017/S095834401200002X

Hashemi, M., \& Azizinezhad, M. (2011). The capabilities of Oovoo and Skype for language education. Procedia- Social and Behavioral Sciences, 28, 50-53

Hedge, T. (2000). Teaching and learning in the language classroom: Oxford handbooks for language teachers. Oxford, U.K.: Oxford University Press

Jannah, W., \& Hartono, R. (2018). Students' Speaking Assessment Used by English Teachers Based on the 2013 Curriculum. 8(01), 359-369.

Latif,Amiruddin.(2013). Using storytelling to increase speaking performance of PAI students of Muhammadiyah University of Metro.ISSN 2089-33456.Vol 2 No 2, oktober 2013

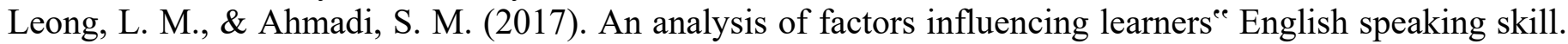
International Journal of Research in English Education, 2(1), 34-41

Pallotti, G. (2009). CAF: defining, refining and differentiating constructs. Applied Linguistics, 30(4), Oxford University Press. 590-601. doi:10.1093/applin/

Richard, C. (2009). Teaching Listening and Speaking. New York: Cambridge University Press.

Richards, J. C., \& Richard S. (2002). Longman: Dictionary of Language teaching and applied linguistics. England: Pearson Education Limited. 